\title{
En Tránsito. Desplazamientos Nimios en el Cine Latinoamericano (2000-2010)
}

\section{On the Way. Trivial Travelling in Latin American Cinema (2000-2010)}

\author{
Luis Valenzuela Prado \\ Facultad de Letras, Pontificia Universidad Católica de Chile \\ Ivalenzp@uc.cl
}

Resumen - este artículo busca poner en escena y analizar ciertos tránsitos, heterogéneos en su consumación, en el cine latinoamericano (2000-2010). Indaga, a partir de algunas reflexiones de Marc Augé, Isaac Joseph y Michel de Certau, las posibilidades de tránsito, como la idea del "andar que enuncia", propuesta por De Certau. Además, analiza los desplazamientos nimios de sujetos omitidos por discursos macropolíticos o cuyo andar pasa desapercibido en el espacio y paisaje donde se desenvuelven. La construcción de este tránsito sienta sus bases sobre claves como la pobreza, el subdesarrollo, la inmigración, la muerte, el viaje.

Palabras clave: Cine latinoamericano, tránsitos, micropolítica, viaje.

Abstract - This article intends to enfatize and analize movements that are different in their consumation in Latin American cinema. The paper studies, through the reflexions of Marc Augé, Isaac Joseph and Michel de Certau, the posibilities of movement as the "enunciating travel" that De Certau proposes. Besides, analizes the trivial travelling of subjects that are omitted by the macropolitical discourses, and whose passing goes out of notice in their spaces and places. The construction of this movement is based in certain keys, such as poverty, underdevelopment, immigration, death and travel.

Key words: Latin American cinema, transits, micropolitics, travel. 
Los tránsitos en una ciudad o en cualquier espacio son eternos e inabordables. Dejan huellas inidentificables. Quienes los llevan a cabo pasan desapercibidos en la escena macropolítica, por lo que se constituyen desde la intrascendencia e insignificancia para esa escena, paisaje, espacio o en especial, discurso, y terminan configurándose como relatos micropolíticos. Recorrer tránsitos — redundancia efectiva y efectista-, es decir, leer las huellas que se hacen difusas en su combinación o cruce con otras huellas. Todo es viaje: viajes por carreteras, parajes campestres o urbanos; el caminar de un dandy, de un flaneur, de un vagabundo por la ciudad o sitio eriazo; los recorridos, marchas y protestas sociales de un sujeto crítico, insomne, apocalíptico; el desplazamiento rutinario de un oficinista o una enfermera; el viaje desesperado hacia el auto-exilio desideologizado.

Tránsitos leídos desde lo micropolítico, en desmedro de lo macropolítico: «En los intersticios de las grandes estrategias políticas - espacio macropolítico-, en conjunción o disyunción con ellas, se tejen pequeños espacios reticulados que diseminan otras estrategias y otros sistemas de fuerzas, que diseñan disputas tapadas por las sombras de los grandes hitos con que se compone la historia» (García, 12). Tránsitos atorados en estos intersticios, tránsitos que tejen y diseñan espacios y discursos desde la nimiedad. «Biopolíticos», en términos de Roberto Espósito, esos donde «la vida misma se sitúa en el centro de cualquier procedimiento político: ya no es concebible otra política que una política de la vida» (26). Relatos biopolíticos cuyo eje es el tránsito y desplazamiento cotidiano o la evasión sobre ruedas, con escasa planificación, sin otro motivo que el moverse. Para Foucault la «biopolítica» tiene como eje «ese algo que llamamos población» (41), cuyo control no solo es ideológico, sino corporal, es decir, enfatiza el objeto de este estudio, el desplazamiento singular, el cuerpo en tránsito.

Para Michel De Certeau el andar citadino configura una enunciación: «el andar parece pues encontrar una primera definición como espacio de enunciación» (110). Al andar se enuncia: «La historia comienza a ras del suelo [...] Las variedades de pasos son hechuras de espacios. Tejen los lugares» (109). Si bien De Certeau analiza los tránsitos citadinos, no es un despropósito pensar que todo tránsito puede ser leído. Así, el autor sostiene que:

sin duda alguna, los procesos del caminante pueden registrarse en mapas urbanos para transcribir sus huellas (aquí pesadas, allí ligeras) y sus trayectorias [...] Pero estas sinuosidades en los trazos gruesos y en los más finos de su caligrafía remiten solamente, como palabras, a la ausencia de lo que ha pasado. Las lecturas de recorridos pierden lo que ha sido: el mismo acto de pasar. La operación de ir, de deambular, o de "comerse con los ojos las vitrinas» o, dicho de otra forma, la actividad de los transeúntes se traslada a los puntos que componen sobre el plano una línea totalizadora y reversible (109).

De Certeau pone énfasis en el tránsito y en la mirada, algo que es proyectable en Marc Augé, para quien el viaje: «construye una relación ficticia entre mirada y paisaje» (91). Para Augé el espacio procede de un «doble desplazamiento", el del viajero y el de los paisajes «de los cuales él no aprecia nunca sino vistas parciales, instantáneas», sumadas y mezcladas en su memoria y, literalmente, recompuestas en el relato que hace de ellas» (90-1). Agregando, por un lado, que en ocasiones el viajero toma la posición del espectador y, por otro, que su espacio de viajero «sería, así, el arquetipo del no lugar» (91), es decir un espacio no fijo.

Una posibilidad de comprender el tránsito es a partir de los conceptos de emigrante y de nómada. Para Isaac Joseph, por ejemplo, el emigrante no es lo mismo que el nómada, ya que éste se encuentra «estabilizado en el movimiento, de alguna forma está estabili- 
zado en el viaje», se desplaza con su tribu, pero también en ella. Diferente es el caso del emigrante que «ha roto los vínculos de parentesco, por lo menos por un tiempo» (73), su ruptura con su entorno es mayor. Los movimientos de estos sujetos podrían erigirse como tránsitos críticos o sintomáticos de una crisis. Para Gonzalo Aguilar afirmar que en la «tendencia nómade se produce un desplazamiento hacia los descartes del capitalismo» sería extraña en un medio como el cine tan ligado a intereses económicos. Por tal motivo sería «importante definir ante qué tipo de desplazamientos nos encontramos, y qué dimensiones simbólicas y materiales se ponen en juego» (43).

De este modo, llego a un corpus amplio de cine latinoamericano ${ }^{1}$, en ningún caso totalizador y acabado, una panorámica que intenta encauzar y a la vez abrir espacios y por qué no, tránsitos. Películas que vienen a tejer una red a partir de las huellas que dejan sus estéticas y sus temáticas abordadas. Estas últimas se mantienen constantes con la tradición, "configurando la personalidad del cine latinoamericano» desde los años 60, es decir, "preocupaciones sociales, políticas y éticas, que se manifiestan en la mayoría de las películas más recientes, cualesquiera que sean los géneros o las estéticas en las que se inscriban», como el exilio en Cuba, la violencia en Brasil, el «acercamiento a los grandes problemas nacionales de la crisis económica y de la memoria de la dictadura desde la perspectiva de historias personales y anecdóticas en Argentina o Uruguay» (Amiot 33).

Las películas son las siguientes²: de Argentina Historias minimas (2002) de Carlos Sorín, Familia rodante (2004) de Pablo Trapero, La dignidad de los nadies (2005) de Fernando Pino Solanas y Los muertos (2005) de Lisandro Alonso; de Bolivia, en ¿Quién mató a la llamita blanca? (2006) de Rodrigo Bellot; de Colombia Paraíso Travel (2008) de Simón Brand; de Chile Dos hermanos (2000) de Martín Rodríguez, Nema problema (2001) de Cristián Leigthon y Susana Foxley, Un hombre aparte (2002) de Betina Perut e Iván Osnovikoff, El corredor (2004) de Cristián Leigthon, Machuca (2004) de Andrés Wood, Play (2005) de Alicia Scherson y Alicia en el país (2008) de Esteban Larraín; de México Y tu mamá también (2001) de Alfonso Cuarón y Japón (2002) de Carlos Reygadas; de Perú La teta asustada (2008) de Claudia Llosa; de Uruguay El baño del Papa (2007) de César Charleone y Enrique Fernández.

Si bien todo puede ser un tránsito, en estas películas están en juego tránsitos específicos de los «nadies", de futuros muertos en Japón y Los muertos, de criminales en ¿Quién mató a la llamita blanca?, de una enfermera mapuche en Play, de adolescentes vagos en Y tu mamá también, de inmigrantes en Alicia en el país y Paraíso travel. Un cine latinoamericano que "se centra en historias mínimas», como parte de una «tendencia a rechazar un acercamiento general a la realidad, para privilegiar argumentos más personales — familiares, íntimos - que les permiten tratar la realidad desde una perspectiva más cotidiana y menos espectacular» (Amiot 35). Un cine latinoamericano donde se alza la «metáfora del laberinto» con y sin salida ${ }^{3}$ (López Pérez y Vergara Estévez, 61).

A pesar de no incluir películas brasileras, mantengo denominación «latinoamericano».

Los viajes del viento (2009) de Ciro Guerra; Negocio redondo (2001) de Ricardo Carrasco, Taxi para tres (2001) de Orlando Lubbert, El viaje de Teo (2008) de Waler Doehner; El viaje hacia el mar (2003) de Guillermo Cassanova.

3 En el primer caso los autores citan Machuca y Martin Hache, mientras que en el segundo Carandirú y Tony Manero, entre otras. 


\section{EL TRÁNSITO DE LOS NADIES}

¿Quiénes son los nadies? Un sistema de sujetos ninguneados, situados en un intersticio sin poder, subalterno. La dignidad de los nadies ${ }^{4}$ de Fernando Pino Solanas escenifica la historia de los nadies, "de mujeres y de hombres argentinos, sin recursos y sin nombres", «el pueblo del aguante, que lleva como bandera su coraje y dignidad». Los «nadies» son los que, crisis más o crisis menos, siempre siguen ahí, son los que están estancados. Los «nadies» serán los que llevan un tránsito nimio e intrascendente para el sistema, tránsito que no cambia en nada el entorno, tránsito a veces crítico o a veces inconciente, pero que en su «andar» va dejando huellas que pueden ser leídas.

En este marco La dignidad de los nadies busca dar con estos personajes que transitan por un sistema político en ruinas. Solanas parte de un contexto político dado por la incesante rotación de presidentes: De la Rúa, Rodríguez Saá, Duhalde, Kirchner. Además de una estrepitosa devaluación económica y una continua movilización social: el pueblo va a la calle, junto con la clase media empobrecida, indigentes y piqueteros. De este modo, el documental da cuenta de un país "en estado de asamblea», con un pueblo que "quiere participar, tener voz», que sabe lo que quiere, "pero no cómo lograrlo».

Uno de sus personajes es Martín Galli, un escritor motoquero que se une al grupo de críticos sociales, con «calor en la sangre». Se involucra en una lucha contra el sistema en medio de gente como él, común y corriente. En medio de esas manifestaciones recibe una bala en la cabeza, disparada por un policía. En ese momento aparece el Toba, quien lo asiste y ayuda. Así, el documental sigue el camino del Toba, un sobreviviente de la dictadura argentina. Vive en la periferia, sustenta ese espacio, pero transita hacia el centro, en su labor de profesor. Es seguido por la cámara en sus recorridos, por los comedores comunitarios en Matanza, una organización para sustentar el comedor para luchar contra el hambre. El documental vuelve a poner en escena la idea de «ceder la voz», una ilusión estética y narrativa que bien sabemos imposible. Sin embargo, de igual forma hay un cruce interesante de voces de los «nadies» y la voz del director.

Campamentos piqueteros, la espera de un grupo, la búsqueda de trabajo, hombres y mujeres que viven con lo básico. Margarita Colinche dice haber aprendido a «vivir con nada», recolecta basura, botellas, cartones. Vive del residuo. Hay una preocupación especial por los niños y niñas que no tienen qué comer ni van a estudiar. La política parte de los cimientos sociales. Antonia Delgado habla del comedor pobre. Rufino Romero y Chipi (el cocinero), cocinan hasta para 289 personas, a veces solo con cebolla.

Así, La dignidad de los nadies transita entre estos dos espacios. La periferia y el centro. Plaza de Mayo, la protesta, la marcha política de los piqueteros construyendo tránsitos, pero también cortando caminos/tránsitos. Cortan las rutas, intervienen la circulación del país. El movimiento no cesa, es literal, se mueven a través de la carretera: «Acampando en los caminos como los ejércitos del siglo XIX, los piqueteros se instalaron con sus familias, sus perros y caballos. Los campamentos recrean la experiencia de veinte años de tomas de tierras y asentamientos urbanos. Su organización abarca primeros auxilios, alimentación, seguridad, cursos y asambleas» (Pino Solanas, La dignidad de los nadies).

\footnotetext{
Es la segunda película de Pino Solanas sobre la crisis argentina. La primera fue Memoria de un saqueo.
} 
No obstante, a pesar de todo lo anterior, las elecciones del 2003 constatan lo siguiente: siguen gobernando los mismos. Pino Solanas erige una crítica explícita al poder popular que no logra organizarse. Sin embargo, los «nadies» siguen ahí, y lo insignificante de sus desplazamientos se vuelve, de manera simbólica, en una inercia intrínseca de los personajes que busco analizar, inercia cuyo recorrido puede ser leído desde un «andar» que algo nos dice, desplazamiento de un grupo de sujetos que corren por surcos nimios e intrascendentes.

\section{FUGAS INÚTILES O TRÁNSITOS MÍNIMOS}

El viaje intrascendente o mínimo ${ }^{5}$ es presentado como el desplazamiento enquistado en un sujeto, el germen del tránsito que se manifiesta por medio de la obsesión. Un ejemplo patente de esta obsesión es El corredor, documental en el que es posible apreciar el viaje rutinario de Erwin Valdebenito, «el modo de la monomanía o de la idea fija» del movimiento «como fuga o carrera inútil» (Corro, 355), a través de su recorrido diario de 22 kilómetros desde su casa en San Bernardo hasta el centro de la ciudad. A partir del seguimiento de su recorrido, la respiración jadeante del protagonista en primer plano de sonido, enfatiza el ritmo obstinado de un desplazamiento, cuyo recorrido es leído desde este sujeto que se configura en el movimiento.

Play propone un tejido trazado con tránsitos, con bolsas de basura, con sujetos desechados (Tristán es desechado por su esposa, unos obreros reclaman al ser despedidos), con residuos de los mismos, con lo escatológico como tema. ${ }^{6}$ El tránsito de Cristina es la opción personal por reconstruir la vida del dueño (Tristán) del maletín que ella encuentra en un contenedor de basura. Es una película en tránsito, en apariencia desligada de todo elemento ideológico. Sin embargo, para Jorge Ruffinelli, si bien «se encuentra lejos de ser un cine de preocupación social al modo acostumbrado", está llena "de todas sus marcas: un paro en la construcción, la diferencia social por etnias (criollos y mapuches), la diferencia social por barrios de la ciudad [...], el problema de los asaltos en las calles; los problemas de las relaciones de parejas» (258). Todas estas películas cuentan con protagonistas que realizan sus viajes, independiente de que éstos sean irrisorios o inabordables. Levantan un gesto de empecinamiento subjetivo, simbólicamente micropolítico.

Historias minimas presenta el viaje solitario de tres personajes por la Patagonia austral de Argentina: Don Justo, Roberto y María Flores. Sus tránsitos pueden ser leídos desde lo mínimo, es decir, lo sencillo, pero también lo modesto. Cuerpos en movimientos, desplazamientos intrascendentes para el sistema, motivados por una idea fija que se enquista en sus vidas. Los planos cerrados los muestran en contraste con planos abiertos, de un paisaje en apariencia inabarcable, que encuadran la soledad que viven. Al posar la mirada sobre ellos queda de manifiesto un interés por lo sencillo en desmedro de la gran gesta, la opción

Este viaje también se manifiesta en Los viajes del viento, donde un juglar recorre grandes distancia solo para entregar un acordeón. El viaje hacia el mar es el viaje de un grupo de viejos amigos que no conoce el mar y decide hacerlo en camión.

6 Idea trabajada en la ponencia «Restos y residuos citadinos en el cine chileno, 2001-2010», presentada en el Tercer Simposio de Estéticas Americanas, organizado por el Instituto de Estética de la Pontificia Universidad Católica de Chile. 
de una fuerza micropolítica y no macropolítica. Es posible que sus motivaciones a nadie le interesen, solo a ellos. Don Justo, de 80 años, va en busca de Malacara, el perro que hace tiempo lo abandonó; Roberto, de 40 años, es un vendedor viajero cuyo objetivo es llevar una torta para el hijo de una amiga a la que quiere conquistar; María, de 25 años, va a un canal de televisión de provincia en busca de un premio que ganó.

Roberto lee en voz alta un libro sobre ventas: «nunca considero un fracaso como un fracaso sino como una oportunidad para cambiar el mundo». Roberto hace su viaje como un ganador, sin embargo, vive de esperanzas mínimas. Todo su viaje está impregnado de optimismo, su destino es el amor, y para conseguirlo lleva una torta para el hijo de una mujer que le atrae. Tanto el viaje de Roberto, como el de don Justo y de María, evidencian relatos cotidianos y mínimos. Diálogos en tránsito, como el que sostienen Roberto con don Justo, cuando se cruzan en la carretera, sobre la torta que lleva el primero o sobre el cálculo de los kilómetros recorridos en sus 20 años de trabajo: 2.600.000 kilómetros, «¿Usted cree que me van a dar un premio por eso?» claro que no, su vida es mínima, por ende no es tomada en cuenta. Sus relatos, mínimos, sencillos, de «nadies», son uno más dentro de un infinito de posibilidades.

Familia rodante escenifica el viaje colectivo que busca enmendar el rumbo de una familia disgregada, intentando unirla por medio del mismo viaje. La película se lleva a cabo "casi toda en una casa rodante» desde San Justo a Misiones, sin embargo, sería más que una narración nomádica, incluso «sedentaria», ya que, según Gonzalo Aguilar: «Hay familia, hay casa, aunque sean rodantes» (41), lo que la hace estática. Estática y encerrada, enclaustrada en su dinámica familiar, pero también en la claustrofobia de la casa rodante. Planos cerrados al encierro del viaje, detalle a los objetos y partes del cuerpo - la mirada incestuosa entre primos- y a las rutinas viajeras como la posición de las manos al dormir, servir el té, fumar. "Somos como una gran familia que rueda / rueda y rueda para sacarse las penas / de un gran corazón que palpita por viajar» dice la canción de León Gieco que acompaña el inicio del viaje. Una familia trizada que rueda para sacarse la penas, para salvarse, para intentar reconstruirse, pero que cae una y otra vez en la discusión, en el reproche.
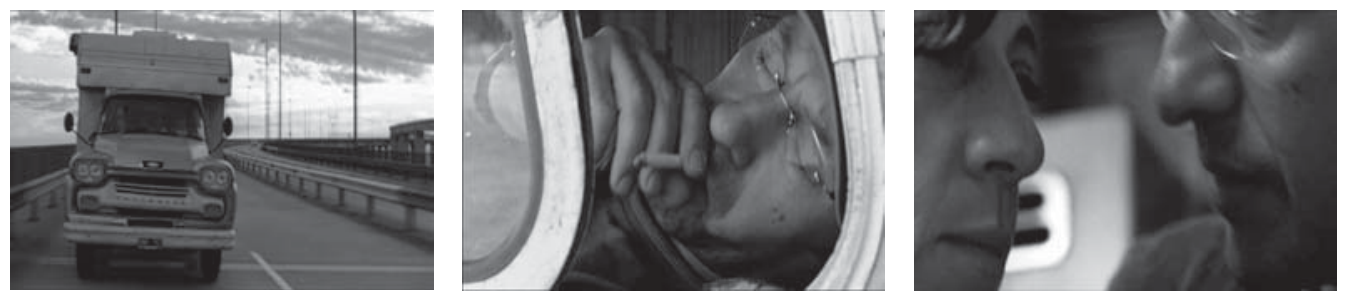

Imagen 1, 2 y 3 . El tránsito familiar de Familia rodante.

Retomando a Augé, todo viaje implica a un viajero y un paisaje, afirmación que calza en éstas y en la mayoría de las películas analizadas. El sujeto en tránsito se desplaza, y en esa acción se está compenetrando con su entorno. El sujeto interviene ese espacio, rompe la estaticidad de ese paisaje, como lo hace Cristina en su obsesiva búsqueda de reconstrucción de Tristán; o Roberto en su intento por llegar a salvo con su torta; o Valdebenito en su obcecada rutina de corredor. 


\section{LOS RECORRIDOS DEL INMIGRANTE}

La figura del inmigrante en el cine latinoamericano me lleva a pensar en la búsqueda personal de un exilio, implícitamente movida por ciertas injusticias sociales. Para Isaac Joseph «La experiencia del emigrante se caracteriza por una obsesión: la pérdida del sentido del mundo» (31). El emigrante rompe sus parentescos, pasa por la prueba de «la coexistencia desgarradora del recuerdo y del olvido» (73). Sus identidades son identidades en tránsito fronterizo. Alicia en el país narra la historia de una niña boliviana de 13 años que camina a pie hasta San Pedro de Atacama para buscar trabajo. Recorre 180 $\mathrm{kms}$ entre desierto, nieve y salares. Camina, por lo que sus pies son su medio principal. El paisaje se amalgama con Alicia. Observa, cruza la frontera ${ }^{7}$.

Paraíso travel — basada en la novela del colombiano Jorge Franco- también pone énfasis en la búsqueda del sueño americano, siendo presentada como un relato de aprendizaje, donde el viaje de Marlon y Reina desde Medellín hasta Nueva York, tiene un carácter formativo. El nombre "Paraíso», unido al descenso a diversas áreas de la ciudad (sótanos, subways, burdeles), funciona alegóricamente con el paraíso y el infierno de la Divina Comedia de Dante. Dentro de esa perspectiva, el infierno urbano está vinculado tanto a Colombia como a Nueva York, junto con el paso por el río de Guatemala a México. Hay también una idea laberíntica de la ciudad, la cual estaría relacionada con el mito de Ariadna, quien ayuda a Teseo a vencer al Minotauro. En las primeras escenas se ve a Marlon escapando de la policía, pero sobre todo, ingresando a un laberinto del cual le costará escapar. Cruza el plano, avanza en profundidad de campo, y viene desde ésta (imágenes 4, 5 y 6). En la película Marlon intenta ayudar a Reina para conquistar a la Bestia/monstruo. Van juntos, pero olvidan el hilo y se pierden en el laberinto.
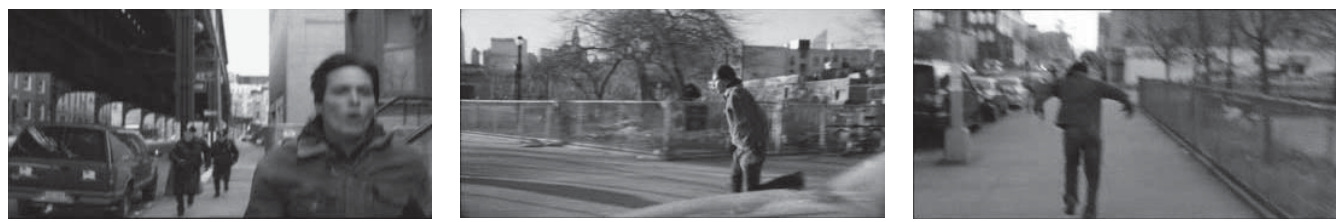

Imágenes 4, 5 y 6. Ingreso al laberinto en Paraíso travel.

En Paraíso Travel la ciudad es presentada como infinitos puntos de encuentro, como por ejemplo en esa idea de Marlon de haberse cruzado con Reina, pero siempre estar extraviado en una ciudad extraña y hostil. Nueva York como el lugar donde hay plata y trabajo para todos, como dice Reina que le cuenta Gloria. A partir del descenso a ese infierno laberíntico, queda latente la idea de que en Colombia/Medellín, están todos jodidos. Hay una imagen desencantada de Colombia, a la vez. El inmigrante es planteado como mercado, escenificado en la figura de Fabiola, la cual lucra consiguiendo papeles y documentos para viajar: «Paraíso Travel». La condición del inmigrante, expuesto a una

Por su parte, El viaje de Teo da cuenta, como viaje de formación, del intento por cruzar la frontera de México y EE.UU. 
nueva cultura, a una nueva lengua y un nuevo horizonte de expectativas que se debe negociar entre la cultura local y la cultura global, residente en Nueva York.

Por su parte, Nema problema narra la gesta heroica de un grupo de veintiséis refugiados de la ex Yugoslavia, serbios, bosnios y croatas, que buscan un lugar donde establecerse. Este documental tiene una bajada que antecede al título: Donde no hay refugio posible... Nema problema, es decir, frente a la adversidad y el desarraigo, no hay problema. Todos sus protagonistas son «víctimas de la guerra de los Balcanes a comienzos de los años noventa»; identificados desde su anonimato, desligado de cualquier presencia pública en su país de origen, arriban a Chile sin memoria para intentar construir una nueva vida. Su heroicidad no se manifiesta en el triunfo, sino por el contrario: se construye a partir de la desgracia, el viaje esperanzador hacia Chile y el choque cultural sufrido cuando no consiguen lo que ellos esperaban.

El documental registra el arribo de estos refugiados desde cerca, su esperanza y sus dudas por encontrar un lugar en Chile. El entusiasmo inicial del grupo se diluye con el paso de los días, semanas y meses. La heroicidad de esta gesta colectiva extranjera se comienza a ver en el desgaste cotidiano, cuando van revelando su molestia con la comida que les dan en el hogar, situación expresada por la cocinera y luego expuesta cuando uno de los refugiados bota su comida a la basura. De esta forma, comienzan a mostrar sus diferencias con el proyecto. Algunos se inclinan por criticar a quienes les ofrecieron este sueño de desplazarse desde su país natal a Chile, un país del que solamente les dijeron "que era un país bonito", acompañado de un folleto que lo ilustraba, sin comentarles, por ejemplo, que en Chile no había seguro social. De cierta forma, se aprecia una heroicidad pendiente, ya que la gesta de este grupo queda truncada. La frustración los va haciendo olvidar el sueño o la idea de conseguir frutos en Chile. Quizá su heroicidad colectiva se manifiesta a partir de la idea de no aceptar lo mínimo y reclamar, con justa razón, las condiciones que les aseguraron.

El emigrante, expuesto a una nueva y extraña cultura, al ser extranjero se convierte en un "tartamudo social», "obligado a traducir los esquemas de interpretación de la realidad palabra por palabra; está aislado de su saber de origen y siempre al borde del mapa, en el límite del territorio que éste abarca» (74). Este aislamiento no obliga a estar traduciendo la nueva cultura que enfrenta.

\section{LA MARCHA DEL TRAMPOSO}

En su artículo «Tramposos», Pablo Corro lleva a cabo un análisis de la figura de este personaje en el cine latinoamericano, entre 1996 (Profundo Carmesí) y 2004 (Mala leche). El tramposo será un "personaje cazafortunas, oportunista», un pillo, «cuya habilidad consiste en encontrar el resquicio» para lograr su objetivo (Corro, 87). Una de las películas que analiza Corro es Un hombre aparte ${ }^{8}$, a la que agrego El baño del Papa y ¿Quién mató a la llamita blanca?, teniendo las tres en común la idea de la trampa menor, del negocio/estafa nimios en tránsito, que luego devienen fracaso. No obstante, todas estas

\footnotetext{
También analiza Profundo carmesí, Taxi para tres, Nueve reinas, La fiebre del loco y Negocio redondo entre otras.
} 
figuras tramposas muestran el intento de hacer trampa al sistema, pero fracaso del mismo intento. Detrás de estos personajes hay una crítica desde la estafa mínima al sistema.

El baño del Papa pone en escena a Beto, quien ve en la visita del Papa Juan Pablo II a Melo, pueblo pobre de la frontera Uruguay con Brasil, la posibilidad de un negocio. Beto es un contrabandista sin éxito, cruza a diario la frontera en busca de negocios. Es una especie de pillo sin suerte, que siempre merodea la derrota y más cuando después de instalar un baño para los peregrinos, fracasa al suspenderse la visita del Papa Juan Pablo II. Su oportunismo es intrínseco, pero fallido. Su tránsito froterizo es cotidiano, su tránsito previo a la frustrada visita del Papa lo ejecuta con un inodoro en los brazos. La imposibilidad de Beto de triunfar en sus «negocios» es la metáfora de las trabas que el sistema les impone.

El documental Un hombre aparte es la historia de Ricardo Liaño, un hombre solo, sin otro sino que el descenso al infierno, sin matices; es la historia de un fracaso por antonomasia. Un sujeto que en otra época fue «alguien» en la escena boxeril, pero cuyo presente lo muestra abandonado. Liaño recuerda su éxito pasado y espera reeditarlo. Éxito revelado fugazmente a partir de algunas fotografías suyas. Éste afirma haber estado con Pablo Picasso, con Salvador Dalí, Alain Delon, haber traído a Julio Iglesias: «Triunfé en la vida, seguiré triunfando en la vida, porque uno nace triunfador y otro nace perdedor». Su pasado se oye falso: "Fui dos veces millonario en dólares, no en pesos», afirmando que volverá a serlo. De ahí surge la segunda etapa, marcada por el ambicioso proyecto de Liaño, la campaña «Un dólar al año, la primera campaña mundial infantil juvenil antidroga», cruzada que da cuenta de sus rasgos de «pícaro» y "tramposo» (Corro, 2004), que desemboca en el fracaso. Su derrota es expuesta en la espera final representada en el documental, con un Ricardo Liaño solo y triste en su habitación en una pensión en el barrio Mapocho, cerca de calle Bandera, espacio que contrasta con el ánimo ganador del comienzo. Una cámara estática hace un contraste entre la luz exterior del día y la luz tenue del encierro durante el día en la pensión y oscuridad en la noche. Así, el recorrido de Liaño representa la caída del héroe, el cual ni en su calidad de hombre público ni privado tiene éxito. Su lugar es otro, el de un hombre aparte.

Por su parte, en ¿Quién mató a la llamita blanca? el tránsito nimio de Los Tortolitos (Jacinto y Domitila, protagonistas) se funda en la misión que tienen de llevar un cargamento de cocaína desde Bolivia a Brasil. Su viaje es seguido por tres vías: la policía, la televisión y un narrador camaleónico y omnisciente. Este último mimetizado con el entorno, como personaje secundario en distintas escenas, disfrazado de sacerdote, de vendedor de minutos para celular, de indígena, entre otros. La gesta de Los Tortolitos permite analizar la manera en que la película configura un relato de "país», poniendo de manifiesto la identidad de los bolivianos a partir de una autocrítica social a su idiosincrasia, como es definida en la misma: "paraíso del subdesarrollo».

El «narrador camaleónico», un sujeto caminante, que en tránsito constante, peregrina y acompaña los pasos de Los Tortolitos, configura el relato de la película y del país, a «ras de suelo", ya que teje un relato, urde una narración. Su ubicuidad, en general manifiesta en el cine desde una omnisciencia de cámara neutra o anónima, permite estar presente en diversos lugares a la vez. Benjamin afirma que con la Guerra Mundial «¿No se advirtió que la gente volvía enmudecida del campo de batalla?» (60). Esta idea pone en escena la hipótesis de que después de un período de «crisis» la "gente» calla, por lo que la vuelta al habla es un tránsito desde el silencio, pasando por el balbuceo, hasta alcanzar 
el momento cuando el discurso fluye — aunque no en todos los ámbitos de la sociedad-, enunciando lo antes silenciado, pensando sobre las ruinas las posibilidades que ofrece el futuro.

El tránsito de Los Tortolitos pone de manifiesto la presencia de un road movie latinoamericano, cuyo eje, como sucede en el road movie estadounidense, es la carretera en tensión con el interior del auto que los traslada (imágenes 7 y 8). Así, la marcha del tramposo es el desplazamiento del sujeto que intenta e incluso alcanza a palpar el triunfo de su relato que le permita torcer la mano al sistema y estafarlo. Sin embargo, su destino está marcado por una derrota, ya que siempre el sistema al que intenta burlar estará más preparado para salvarse de todo perjuicio o trampa que intenten jugarle.
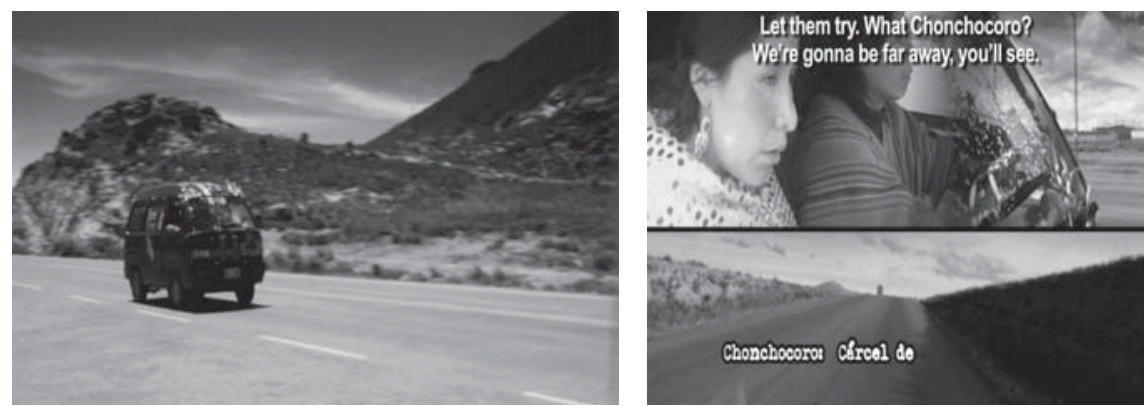

Imágenes 7 y 8 . Tránsito de Los Tortolitos.

\section{VIAJE DE APRENDIZAJE INFANTIL Y ADOLESCENTE}

Tanto Y tu mamá también como Machuca dan cuenta de relatos de aprendizaje, de viajes de formación que atraviesan carreteras o ciudades, pero también, en ambos casos, clases sociales. Para Jorge Ruffinelli la primera es un road movie que trama la iniciación sexual de los adolescentes, los «desmadrosos héroes chánganos diecisieteañeros» (Ayala, 133), Tenoch y Julio, con el contexto socio-político. El primero marca el tabú que da cuenta de «la sospecha de que toda amistad masculina implica elementos eróticos» (Ruffinelli: 240), lo que sumado al ménage a trois en tránsito junto a Luisa (Maribel Verdú). El segundo, dado por «la evidente disparidad social» entre Tenoch y Julio, y por la presencia de clases poderosas, satirizada por un narrador que comenta las acciones de esta clase: «en una oportunidad se refiere a un episodio de corrupción económico-política de la familia de Tenoch», ejemplo que junto a otros, según Ruffinelli, «demuestra que la película no es inocente ni virgen, sino cargada ideológicamente» (241). El tránsito adolescente de esta película pone de manifiesto el fluir de un relato paralelo a la historia de un país como México, leído desde la corrupción.

El desplazamiento nimio de Tenoch, Julio y Luisa es un escape colectivo, inconsciente si se quiere, pero evasivo de una realidad social. "Cuando quienes se ponen en movimiento son los adolescentes, como [...] en Y a tu mamá también [...], se percibe hasta qué punto la sed vital de cada uno de esos jóvenes vuelca en el espacio la búsqueda que los mueve: desplazarse en el espacio equivale aquí a realizar los gérmenes posibles de vida que ellos 
llevan consigo» (Manzi 2003). La puesta en escena de su tránsito por la carretera recurre a distintas escenificaciones. Intercala el plano cerrado al interior del auto con los tres personajes con el plano general a la carretera y espacio árido y seco. A su vez, cámaras estáticas son atravesadas por el auto de los viajeros o en un travelling semisubjetivo la cámara es la que avanza dejando atrás el paisaje.

Por su parte, Machuca, es el relato que expone el fracaso del cruce de clases. Desde la mirada infantil de Gonzalo Infante y Pedro Machuca, vemos cómo cada uno de estos niños atraviesa el cerco de la clase social para conocer o intentar conocer al otro. Sin embargo, ambos, en su territorio extraño, son rechazados. Al comentar Kamchatka y Machuca, Tzvi Tal sostiene que las dos películas «exponen memorias de niños y adolescentes tempranos que fueron testigos del golpe militar y quedaron marcados por el trauma» (141). Un golpe militar que funciona como telón del fondo al relato de Gonzalo y Pedro, su amistad y sus distancias sociales.

Cuando se manifiesta la posibilidad del viaje, Tenoch y Julio intentan conseguir el automóvil con la hermana de Julio. Lo hacen por entre una marcha colectiva, una protesta social estudiantil. Un plano semi cerrado, una escena fugaz que da cuenta del poco interés por la macropolítica por parte de los amigos. La protesta queda en un segundo plano, al igual que en Machuca, donde Pedro Machuca vende banderas de partidos políticos sin importar el color ideológico de éstas (imágenes 9 y 10 ).
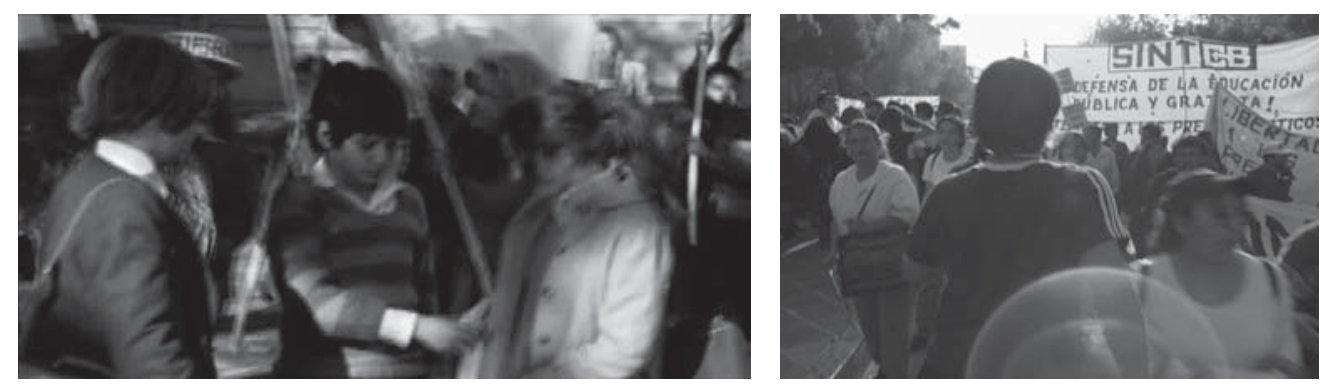

Imágenes 9 y 10. El tránsito desideologizado en medio de la marcha política.

Ambas películas presentan un tránsito, una en auto hacia la playa y la otra en bicicleta por la ciudad, escenificando un «andar» constante, pero a la vez híbrido y amalgamado, en el cual convergen historias con pasados y presentes heterogéneos en sus procesos, aunque igualmente derruidos en el presente, como en el caso de Machuca. Gonzalo, según Ruffinelli, «es la bisagra entre esa clase pobre que visita, y la propia, cruel y corrompida» (254). Los espacios familiares y políticos que están detrás de estos personajes, se caen a pedazos.

En Y tu mamá también y Machuca la amistad en tránsito que los une queda trizada y posteriormente rota hacia el final. En ambas se da el triángulo de iniciación en lo sexual. Si a la amistad de Tenoch y Julio se unía Luisa, en la de Gonzalo Infante y Pedro Machuca se une Silvana, por medio de quien descubren una «sexualidad incipiente, analógica al descubrimiento del conflicto social y la violencia en auge» (Tal, 147). En ambas películas hay un despertar que les abre los ojos a los amigos y que al final termina consolidando el distanciamiento. 


\section{LA MUERTE EN TRÁNSITO}

Las cuatro películas que configuran este punto tienen tres ejes centrales: el tránsito, la muerte y el silencio. Japón muestra en las primeras escenas un auto que avanza por una autopista, luego por una carretera semirrural, hasta llegar a un camino sin pavimentar. La distancia entre la cámara y el paisaje es constante, no varía. Lo que sí cambia es el paisaje mismo, enfatizando el abandono de la ciudad. Japón pone en escena, con un aire rulfeano, a un hombre que abandona la ciudad en busca, en forma literal, de su muerte, cuyo motivo «ni la razón de viajar a un lugar remoto» (Ruffinelli, 250) serán conocidas por el espectador. Es un tránsito de escape, de ida sin regreso, «huyendo de sí mismo, al parecer abrumado por el peso de la civilización» (Ayala, 156), pero también de su existencia. Un viaje de aprendizaje a la inversa, de descenso hacia la muerte. Un viaje ralentizado, silencioso, desolado en vidas y paisajes cuya finalidad es apagar las luces e irse para siempre.

Dos hermanos convida al viaje de Pancho y Pablo a Coquimbo, quienes van en busca del cadáver de su padre, muerto en un accidente en la carretera. El viaje debiera permitirles encontrar física y simbólicamente el cuerpo de su padre, pero también encontrarse ellos como hermanos. Desde el encierro del auto los hermanos enfrentan la carretera, como preámbulo al encuentro con el padre ya muerto.

El tránsito de Justa en La teta asustada también es el desplazamiento silente para encontrar un lugar para la muerte, un espacio donde enterrar el cadáver de su madre. Su pasar está determinado por el temor y el susto exacerbado, que deviene reconocimiento de sí misma. Según Ruffinelli, al final Justa "consigue librarse de los fantasmas que le impiden vivir, a la vez que encuentra el sitio donde enterrar a su madre» (266). A la vez, el tránsito silente de Justa es roto con la presencia del idioma quechua de Justa. Su canto en este idioma la hace romper el silencio del español que casi no usa para comunicarse. Su canto exacerba la idea mestiza latinoamericana y en especial peruana reconocida en palabras de Arguedas como la presencia de un sujeto configurado como «un demonio feliz» que habla en "cristiano y en indio, en español y en quechua». El tránsito de Justa es el tránsito de un idioma que se pierde.

Finalmente, Los muertos relata el viaje de Argentino Vargas que desde la cárcel pasa a la búsqueda de su hija. Al salir de la cárcel intenta recomenzar su vida otra vez. Se desplaza en camioneta, a pie, se detiene, luego toma un bote. El silencio y los tiempos muertos en tránsito abundan. Todo se ralentiza. Las escenas en bote llevan al extremo el movimiento lento. Planos generales a parajes de cauce fluvial extensos, que apenas dan movimiento y velocidad al bote donde viaja Vargas. Tránsito lento y muerto, silente. Así, las "peripecias» del viaje se presentan en su desplazamiento: "la realización de una prueba, el reconocimiento de un amigo o un antiguo amigo, la relación amorosa con una mujer, y finalmente, el reencuentro con su familia» (Aguilar, 76). Su búsqueda se torna indeterminada, ya que, según Gonzalo Aguilar, "el motivo de su viaje termina siendo un cuerpo ausente» (80). Ausencia exacerbada en el vacío de la vida que lleva Vargas, pero también en los silencios que paradójicamente copan la película.

Silencios, ausencias y vacíos son complementarios y exacerbados en estas películas. Sus personajes van al encuentro de la muerte. No claudican al momento de enfrentar el espacio que los separa de ésta. Parajes solitarios como en Japón, la carretera en Dos hermanos, la ciudad en La teta asustada, los ríos en Los muertos. 


\section{TRÁNSITOS}

El tránsito como manifestación de lo nimio en el cine latinoamericano es el desplazamiento que se construye desde la paradoja insignificancia significativa, a partir de la insignificancia del tránsito para una macropolítica, pero desde una traslación singular y significativa para el sujeto que lleva a cabo el desplazamiento. Tránsitos despojados de posibilidades de remecer el poder político y económico. Tránsitos de cuerpos, nómadas unos, inmigrantes otros, pero inofensivos como relatos que, desde su levantamiento estético de las películas que lo escenifican, dan cuenta de cauces de lo micropolítico, tránsitos y los «nadies», fugas inútiles, mínimos, recorridos inmigrantes, marcha de los tramposos, viaje de aprendizaje infantil y adolescente, finalmente, muertes en tránsito. Un tránsito de sujetos cuyo peso es marginal para las instituciones de poder. Leer estos recorridos permite revisar e identificar los mapas micropolíticos que trazan estos relatos, resistencias que corren como cauces paralelos a las decisiones venidas desde el poder político o económico.

\section{REFERENCIAS}

Aguilar, Gonzalo. Otros mundos. Un ensayo sobre el nuevo cine argentino. Buenos Aires: Santiago Arcos Editor, 2006. Medio impreso.

Alicia en el País. Larraín, Esteban, dir. Act. Alicia Esquivel. DVD. Color. Piraña Films, 2008. Medio fílmico

Amiot, Julie. «Formas de la ficción cinematográfica actual en América Latina». Cuadernos Hispanoamericanos 679 (2007). Madrid. 29-36. Medio impreso.

Augé, Marc. Los no lugares. Espacios del anonimato. Una antropología de la sobremodernidad. Barcelona: Gedisa, 2005. Medio impreso.

Ayala Blanco, Jorge. La grandeza del cine mexicano. México: Océano, 2006. Medio impreso.

Benjamin, Walter. «El narrador». El narrador. Santiago: Metales pesados, 2008. 57-97.

Corro, Pablo. «Documental chileno contemporáneo y el <realismo en trance»: una acreditación teórica». Actas del II Simposio Internacional de Estéticas Americanas. Santiago: Instituto de Estética, Pontificia Universidad Católica de Chile, 2009. Medio impreso.

—. «Tramposos». Aisthesis 37 (2007). Instituto de Estética, Pontificia Universidad Católica de Chile. 89-96. Medio impreso.

Dos Hermanos (En un lugar de la Noche). Rodríguez, Martín, dir. Act. Francisco López, Luciano Cruz-Coke. Color. Roos Films, 2000. Medio Fílmico.

El baño del Papa. Charlone, César y Fernández, Enrique, dir. Act. César Troncoso, Virginia Méndez, Virginia Ruíz. Color. Laroux Cine, 2007. Medio Fílmico.

El Corredor (Historia Mínima de Erwin Valdebenito). Leighton, Cristián, dir. Act. Erwin Valdebenito. Video Digital. Color. Surreal, 2004. Medio Fílmico.

Espósito, Roberto. Bíos. Biopolítica y filosofía. Buenos Aires: Amorrortu, 2006. Medio impreso. 
Familia Rodante. Trapero, Pablo, dir. Act. Graciana Chironi, Nicolás López, Liliana Capurro. 35 mm. Color. Alta Films, 2004. Medio Fílmico.

García, Raúl. Micropolíticas del cuerpo. De la conquista de América a la última dictadura militar. Buenos Aires: Biblios, 2000. Medio impreso.

Historias Mínimas. Sorín, Carlos, dir. Act. Javier Lombardo, Antonio Benedicti, Javiera Bravo. 35 mm. Color. Guacamole Films S.A, 2002. Medio Fílmico.

Japón. Reygadas, Carlos, dir. Act. Alejandro Ferretis, Magdalena Flores, Yolanda Villa. $16 \mathrm{~mm}$. Golem, 2002. Medio Fílmico.

Joseph, Isaac. El transeúnte y el espacio urbano. Ensayo sobre la disposición del espacio público. Barcelona: Gedisa, 2002. Medio impreso.

La Dignidad de los Nadies. Pino Solanas, Fernando, dir. 35 mm. Color. Cinesur S.A, 2005. Medio Fílmico.

La Teta Asustada. Llosa, Claudia, dir. Act. Magaly Solier, Susi Sánchez, Marino Ballón. Color. Wanda Visión S.A, 2009. Medio Fílmico.

López Pérez, Ricardo y Vergara Estévez, Jorge. «La metáfora del laberinto en el cine latinoamericano actual». Dossier «Periferias interiores». Revista 18024 (2009). 60-63. Medio impreso.

Los Muertos. Alonso, Lisandro, dir. Act. Argentino Vargas, Francisco Dornez, Yolanda Galarza. 35 mm. Color. Primer Plano Film Group, 2004. Medio Fílmico.

Machuca. Wood, Andrés, dir. Act. Matías Quer, Ariel Mateluna, Manuela Martelli. DVD. Cameo, 2004. Medio Fílmico.

Manzi, Joaquín. «Buscando cobijo. Tránsito de extranjeros en el cine de A. Aristarain y W. Salles». Dossier «Amérique Latine Histoire et Mémoire». Les Cahiers ALHIM 6. Sitio Web. Fecha de ingreso: 2003. Medio impreso.

Nema Problema. Foxley, Susane y Leighton, Cristián, dir. Video Digital. Color. Surreal, 2001. Medio Fílmico.

Paraíso Travel. Brand, Simón, dir. Act. John Leguizamo, Ana de la Reguera, Aldemar Correa. Color. Filmax International, 2007. Medio Fílmico.

Play. Scherson, Alicia, dir. Act. Viviana Herrera, Andrés Ulloa, Aline Kuppenheim. 35 mm. Color. Bodega Films, 2005. Medio Fílmico.

¿Quién Mató a la Llamita Blanca?. Bellot, Rodrigo, dir. Act. Agustín Mendieta, Erika Andia, Miguel Valverde. Video Digital. Abs Production - Barcelona S.L, 2006. Medio Fílmico.

Ruffinelli, Jorge. América Latina en 130 películas. Santiago: Uqbar, 2010. Medio impreso.

Tal, Tzvi. «Alegorías de memoria y olvido en películas de iniciación: Machuca y Kamchatka». Aisthesis 38 (2005). Instituto de Estética, Pontificia Universidad Católica de Chile. 136-151. Medio impreso.

Un Hombre Aparte. Osnovikoff, Iván y Perut, Bettina, dir. Act. Ricardo Liaño. 35 mm. Color. 2002. Medio Fílmico.

Y tu mamá también. Cuarón, Alfonso, dir. Act. Diego Luna, Gael García Bernal, Maribel Verdú. Color. 20th Century Fox, 2001. Medio Fílmico. 